Journal of Zhejiang University-SCIENCE B (Biomedicine \& Biotechnology) ISSN 1673-1581 (Print); ISSN 1862-1783 (Online)

www.jzus.zju.edu.cn; www.springerlink.com

E-mail: jzus@zju.edu.cn

Retraction Note:

\title{
Retraction Note to: Effects of dietary glycerol monolaurate on productive performance, egg quality, serum biochemical indices, and intestinal morphology of laying hens
}

\author{
Min-jie ZHAO ${ }^{1}$, Hai-ying CAI ${ }^{2}$, Meng-yun LIU $^{1}$, Ling-li DENG ${ }^{1}$, Yang $\mathrm{LI}^{1}$, Hui ZHANG ${ }^{1}$, Feng-qin $\mathrm{FENG}^{\dagger+1}$ \\ ${ }^{I}$ College of Biosystems Engineering and Food Science, National Engineering Laboratory of Intelligent Food Technology and Equipment, \\ Key Laboratory for Agro-Products Postharvest Handling of Ministry of Agriculture, Key Laboratory for Agro-Products Nutritional \\ Evaluation of Ministry of Agriculture, Zhejiang Key Laboratory for Agro-Food Processing, Zhejiang University, Hangzhou 310058, China \\ ${ }^{2}$ Zhejiang Key Lab for Chem \& Bio Processing Technology of Farm Product, \\ Zhejiang University of Science and Technology, Hangzhou 310023, China \\ †E-mail: fengfq@zju.edu.cn
}

https://doi.org/10.1631/jzus.B18r0530

Retraction Note to: J Zhejiang Univ-Sci B (Biomed \& Biotechnol) 2019 20(11):877-890

https://doi.org/10.1631/jzus.B1800530

The authors have retracted this article (Zhao et al., 2019) due to significant overlap with a previously published Chinese language article (Liu et al., 2017), including overlap in Table 1, Table 2, Table 3, Table 6, Fig. 4, and part of the results (Sections 3.1, 3.2, 3.5, and 3.7).

All authors agree with this retraction.

\section{References}

Liu MY, Wang JL, Feng FQ, et al., 2017. Effects of glycerol monolaurate on production performance, egg quality, serum parameters, immune organ index and abdominal fat morphology of laying hens. China Poultry, 39(17):24-30 (in Chinese). https://doi.org/10.16372/j.issn.1004-6364.2017.17.006

Zhao MJ, Cai HY, Liu MY, et al., 2019. Effects of dietary glycerol monolaurate on productive performance, egg quality, serum biochemical indices, and intestinal morphology of laying hens. $J$ Zhejiang Univ-Sci B (Biomed \& Biotechnol), 2019, 20(11):877-890.

https://doi.org/10.1631/jzus.B1800530

\footnotetext{
The online version of the original article can be found at https://doi.org/10.1631/jzus.B1800530

Corresponding author

(C) Zhejiang University and Springer-Verlag GmbH Germany, part of Springer Nature 2020
} 